\title{
KONSEP BILANGAN RASIONAL DALAM AL-QUR'AN DAN HUBUNGANNYA DENGAN NILAI-NILAI RELIGIUS
}

\author{
Oleh: \\ Sri Wahyuni Nasution
}

\begin{abstract}
Science all comes from the Qur'an, but many still doubt and even argue that science and the Qur'an are systematically integrated. Because of this problem, the writer wants to prove the relationship between the Qur'an and science is perfectly integrated by examining "The Concept of Rational Numbers in the Qur'an and its Relationship with Religious Values". So from this problem the author makes two formulations of the problem, namely: how is the concept of rational numbers in the Qur'an? and what is the relationship between the concept of rational numbers and religious values? The purpose of the author examines the formulation of the problem, namely: to know the concept of numbers in the Qur'an and to know the relationship between the concept of numbers and religious values. The usefulness of research for Islamic education institutions can be used as a source of knowledge and grip, while for educators this research is expected to be an alternative in improving cognitive values and religious values of children, and for students is expected to increase their pride and faith as Muslims and can prefer mathematics, as well as for researchers to know the concepts of rational numbers in the Qur'an and the concept of rational numbers in contemporary mathematics and their relationship to religious values.

The theories used in this study are theories about rational number systems in the fields of mathematics, religious theories and philosophical sciences and the application of the Qur'anic ulul theory as a supporter of author research. This type of research is Library Research research using descriptive approaches, maudu'i interpretations, deductive thinking, inductive thinking, and philosophical approaches.

The results of the research that the authors get are: the concept of numbers in the Qur'an is also a concept of numbers in Arabic. Rational numbers in the Qur'an are partially studied in text, and therefore use contextual understanding, for example by interpreting zero numbers $(0)$ and mathematical lexical concordances, namely in the form of the relationship of words per word in the Qur'an by using the book Al-Mu'jam Al-Mufarash. In the concept of rational numbers in the Qur'an there is a relationship that is proven to be perfectly integrated and there are religious values in the form of: the belief in the existence of Allah SWT, selfawareness as a servant of Allah, and gratitude for the blessings of Allah. All of this is to describe the power of Allah SWT from the translation of related theories. The results of the discussion are in the form of a relationship in the Qur'an with religious values which can be seen from the interpretation of words from the word "number" to the reference of numbers from rational fractions to the largest number, namely "100,000" which is interpreted in the form indicator of religious value, namely: value gives a purpose or direction of value to give aspiration, value directs someone to behave, value is attractive, value disturbs feeling, and value is related to belief and trust. Because all the words interpreted from the Al-Qur'an
\end{abstract}


translation all have indicators of religious value of at least one indicator, it can be concluded that the concept of rational numbers in the Qur'an has a relationship with religious values.

\begin{abstract}
Abstrak
Ilmu pengetahuan semuanya berasal dari Al-Qur'an, tetapi banyak yang masih meragukan dan bahkan membantah bahwa ilmu pengetahuan dan Kitab AlQur'an hubungannya terintegrasi dengan sistematis. Karena masalah ini maka penulis ingin membuktikan hubungan Al-Qur'an dan ilmu pengetahuan terintegrasi dengan sempurna dengan meneliti "Konsep Bilangan Rasional dalam Al-Qur'an dan Hubungannya dengan Nilai-nilai Religius". Maka dari masalah tersebut penulis membuat dua rumusan masalah yaitu : bagaimana konsep bilangan rasional dalam Al-Qur'an? dan bagaimana hubungan konsep bilangan rasional dengan nilai-nilai religius?. Tujuan penulis meneliti dari rumusan masalah tersebut yaitu : untuk mengetahui konsep bilangan dalam Al-Qur'an dan untuk mengetahui hubungan konsep bilangan dengan nilai-nilai religius. Kegunaan penelitian bagi lembaga pendidikan Islam dapat dijadikan sebagai sumber pengetahuan dan pegangan, sedangkan bagi tenaga pendidik penelitian ini diharapkan dapat menjadi alternatif dalam meningkatkan nilai-nilai kognitif dan nilai-nilai religius anak, dan bagi peserta didik diharapkan dapat meningkatkan rasa bangga dan imannya sebagai muslim serta dapat lebih menyukai matematika, serta bagi peneliti untuk mengetahui konsep bilangan rasional dalam Al-Qur'an dan konsep bilangan rasional pada matematika kontemporer dan hubungannya dengan nilai-nilai religius.

Teori-teori yang digunakan dalam penelitian ini adalah teori tentang sistem bilangan rasional pada bidang ilmu matematika, teori-teori keagamaan dan ilmuilmu filsafat dan aplikasi teori ilmu ulumul Qur'an sebagai pendukung penelitian penulis. Jenis penelitian ini adalah penelitian Library Research dengan menggunakan pendekatan deskriptif, tafsir maudu'i, berpikir deduktif, berpikir induktif, dan pendekatan filsafat.

Hasil-hasil penelitian yang penulis dapatkan bahwa : konsep bilangan dalam Al-Qur'an juga merupakan konsep bilangan dalam bahasa Arab. Bilanganbilangan rasional dalam Al-Qur'an sebagian yang dikaji secara teks, maka dari itu digunakan pemahaman secara konteks misalnya saja dengan penginterpretasian bilangan nol (0) dan konkordansi leksikal matematis yaitu berupa hubungan kata per kata yang ada dalam Al-Qur'an dengan menggunakan kitab Al-Mu'jam AlMufarash. Pada konsep bilangan rasional dalam Al-Qur'an terdapat hubungan yang terbukti terintegrasi dengan sempurna dan terdapat nilai-nilai religius berupa : keyakinan akan adanya Allah SWT, kesadaran diri sebagai hamba Allah, dan rasa syukur akan nikmat Allah. Semua ini untuk menggambarkan kekuasaan Allah SWT dari penjabaran teori-teori yang berkaitan. Hasil pembahasan berupa hubungan bilangan dalam Al-Qur'an dengan nilai-nilai religius yang tampak dari penafsiran kata-kata dari kata "bilangan" hingga penyebutan secara teks bilangan dari bilangan pecahan rasional hingga bilangan yang terbesar yaitu bilangan "100.000" yang diinterpretasikan dalam bentuk indikator nilai religius yaitu : nilai memberi tujuan atau arah nilai memberi aspirasi, nilai mengarahkan seseorang untuk bertingkah laku, nilai itu menarik, nilai mengusik perasaan, dan
\end{abstract}


nilai terkait dengan keyakinan dan kepercayaan. Karena semua kata yang ditafsirkan tersebut dari terjemahan Al-Qur'an semuanya memiliki indikator nilai religius minimal satu indikator maka dapat disimpulkan bahwa konsep bilangan rasional dalam Al-Qur'an memiliki hubungan dengan nilai-nilai religius.

Kata kunci : Konsep bilangan rasional, Nilai-nilai religious

\section{A. Pendahuluan}

Sebagaimana dikutip Caner Taslaman, Galileo mengemukakan bahwa "Matematics is the language in which God wrote the universe (Matematika adalah bahasa yang digunakan Tuhan dalam menuliskan semesta ini)." 1

Mengingat bahasa adalah multidimensi, sekali waktu ia lebih dipahami sebagai alat (tool) dalam pengertian bahasa digunakan untuk berbuat sesuatu, seperti menggunakan pisau untuk memotong. Pengertian bahasa lebih sempit maknanya, yaitu berupa kata-kata yang digunakan untuk mengungkapkan perasaan atau untuk memerintah. Tidak salah jika dikatakan bahwa Man has been defined as a tool-using animal, but his most important tool, the one that distinguished him for all other animals, is his speech. Dengan bahasa, kita mengundang seseorang dan dengan bahasa pula kita memberikan penamaan (naming or labeling) terhadap suatu objek. Namun, dari sisi lain, bahasa bisa juga dilihat sebagai medium dalam pengertian kita tidak saja bisa berbuat sesuatu dengan bahasa (with language), melainkan kita beraktifitas di dalam bahasa (within language). Kita berpikir dan membuat janji dengan (with) dan sekaligus di dalam (within) bahasa. ${ }^{2}$

Sebagai umat Islam, petunjuk yang diberikan Allah sebagai Tuhan Yang Maha Esa dengan media komunikasi bahasanya dikumpulkan dalam teks berupa Al-Qur'an dan Hadist. Al-Qur'an dan Hadist merupakan bacaan yang diulang-ulang, konsep pemakaian ini dapat dijumpai pada salah satu surat Al-Qur'an sendiri yakni pada ayat 17, 18 dan 19 surat al-Qiyamah, yaitu:

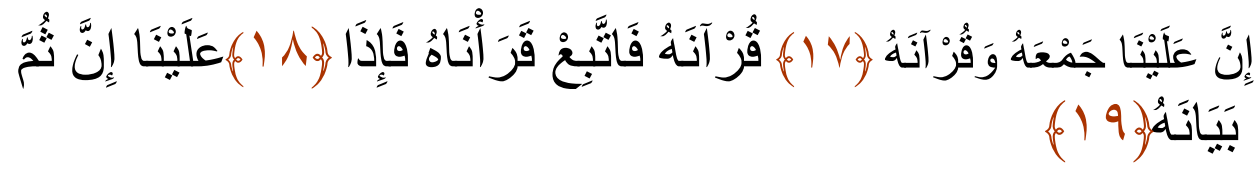

Artinya : Sesungguhnya kami yang akan mengumpulkannya (di dadamu) dan membacakannya. Apabila kami telah selesai membacakannya

1 Caner Taslaman, Miracle Of The Quran: Keajaiban Al-Qur'an Mengungkap Penemuan-penemuan Ilmiah Modern, Diterjemahkan dari "Unchalangeable Miracle" oleh Ary Nilandari (Bandung: Mizan, 2011), hlm. 372.

2 Komaruddin Hidayat, Memahami Bahasa Agama Sebuah Kajian Hermeneutika (Bandung : PT Mizan Pustaka, 2011), hlm. 64-65. 
maka ikutilah bacaannya itu. Kemudian sesungguhnya kami yang akan menjelaskannya. ${ }^{3}$

Logika tentang pernyataan Galileo tersebut bahwa jika matematika adalah bahasa yang digunakan untuk menuliskan keajaiban alam semesta ini, sedangkan bahasa Tuhan adalah bahasa agama, maka dapat disimpulkan bahwa memahami keajaiban alam semesta dengan Matematika dan memahami Matematika dengan bahasa religius atau agama, dalam Islam bahasa agama dituangkan dalam Al-Qur'an sebagai petunjuk, penenang bagi hati kaum muslimin yang bertaqwa dan sumber pengetahuan bagi orangorang yang berpikir.

Sebagaimana dikutip oleh Noeng Muhadjir, sarjana Jerman bernama Leifer menyatakan bahwa ilmu murni bersumber dari Yunani dan tekhnologi bersumber dari Islam. Sedangkan menciptakan tekhnologi perlu mempertimbangkan moralitas, menciptakan seni haruslah sekaligus menumbuhkan rasa indah dan moral, demikian juga ilmu sekaligus rasionalbermoral. ${ }^{4}$ Bukti pernyataan Leifer bahwa tekhnologi berasal dari Islam yaitu lembar sejarah yang menceritakan tentang sumbangsih sains Arab dalam membentuk peradaban Barat seperti : Al-Khawarizmi dalam bidang ilmu matematika, ajaran komprehensif dalam bidang pengobatan dan filsafat dari Ibnu Sina, warisan geografi dan perpetaan Al-Idrisi, atau rasionalisme cermat Ibnu Rusyd. Karya-karya individual ini ialah kontribusi Arab secara keseluruhan di jantung dunia Barat kontemporer yang berdasarkan pada kesadaran bahwa ilmu pengetahuan dapat memberikan kuasa atas alam kepada manusia. Namun fakta yang terjadi adalah keengganan Barat mengakui bahwa sains dan berbagai ilmu pengetahuan lainnya merupakan warisan Arab. ${ }^{5}$

Inilah yang membuat Islam semakin terpuruk, Peradaban Barat yang telah lahir sendiri dengan rekayasa yang menyatakan bahwa peradaban mereka lahir tanpa adanya jasa tokoh-tokoh cendikiawan Muslim Arab. Kemudian Pada Abad 20-an ini keadaan semakin parah karena Islam dimata dunia semakin terjajah, baik dari segi wilayah, pendidikan, tekhnologi, ekonomi bahkan kehidupan sosialnya. Hal ini tampak dari pemberitaan masyarakat muslim dunia seperti Palestina yang hingga hari ini masih terjajah oleh orang-orang Yahudi dan Amerika, bahkan Indonesia juga terjajah dari style dan education. Meskipun demikian, Allah menjamin bahwa jika kita mengembalikan semua masalah kehidupan kita dengan berpedoman pada AlQur'an maka kita bisa selamat di dunia dan akhirat.

Seperti firman Allah dalam Q. S. al-A'raf ayat 156, yaitu :

${ }^{3}$ Departemen Agama RI, AlHidayah Al-Qur'an Tafsir Per Kata Tajwid Kode Angka (Banten: P.T. Kalim, 2010), hlm. 578.

${ }^{4}$ Noeng Muhadjir, Ilmu Pendidikan Sosial Suatu Teori Pendidikan Edisi V, (Yogyakarta: Ravie Sarasin, 1993), hlm. 7.

5 Jonathan Lyons, The Great Bait Al-Hikmah Kontribusi Islam dalam Peradaban Barat (Bandung: PT Mizan Publika, 2013), hlm. 8. 


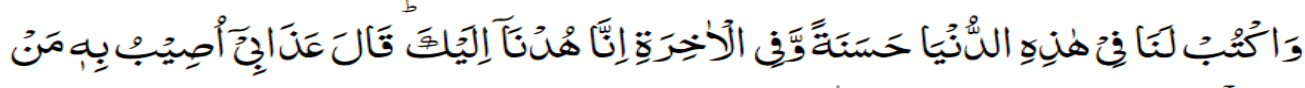

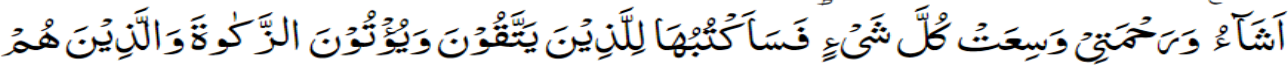

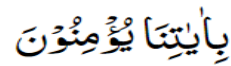

Artinya : Dan tetapkanlah untuk kami kebaikan di dunia ini dan di akhirat. Sungguh, kami kembali (bertaubat) kepada Engkau. ( Allah ) berfirman, "Siksa-Ku akan Aku timpakan kepada siapa yang Aku kehendaki dan rahmat-Ku meliputi segala sesuatu. Maka akan Aku tetapkan rahmat-Ku bagi orang-orang yang bertaqwa, yang menunaikan zakat dan orang-orang yang beriman kepada ayat-ayat kami. (Q.S. al-A'raf:156). ${ }^{6}$

Menurut Al-Ghazali bahwa filsafat diklasifikasikan dalam empat bagian yaitu, Aritmatika, Logika, Ketuhanan dan Fisika. ${ }^{7}$ Matematika merupakan ilmu yang lahir karena kajian dari ilmu filsafat yaitu aritmatika dan logika. Oleh karena itu kebenaran matematika juga berhubungan dengan pembuktian kebenaran yang berasal dari ilmu filsafat. Selain itu Hans Freudenthal dalam Ariyadi wijaya mengatakan bahwa matematika merupakan suatu bentuk aktivitas manusia. ${ }^{8}$ Dengan kata lain bahwa mempelajari matematika sangat berhubungan dengan segala aktifitas manusia, baik ditinjau dari segi ekonomi, sosial, budaya, ilmu pengetahuan dan tekhnologi, dan yang terpenting adalah agama. Salah satu kajian matematika adalah mengenai bilangan. Bilangan merupakan dasar atau pokok dalam melakukan perhitungan dalam matematika, juga pada cabang ilmu sains lainnya. Di dalam Al-Qur'an telah terdapat ganjaran berupa pahala dan ancaman neraka dengan dasar perhitungan dosa, semua ini diberikan Allah keputusan untuk kedua pilihan tersebut kepada manusia dengan proses perhitungan Allah yang sangat cermat. Berarti Allah sudah menginterpretasikan manfaat perhitungan bilangan dalam Al-Qur'an, maka dari itu perlu dikaji lebih dalam tentang konsep-konsep bilangan yang ada di dalam Al-Qur'an dan hubungannya dengan nilai-nilai religius yang dapat dimaknai oleh masyarakat muslim.

Banyak cara mengungkapkan keajaiban Al-Qur'an sebagai bacaan yang mudah dipahami tetapi tidak bisa ditiru, tetapi penulis memilih dengan cara membuat penelitian pengetahuan yang berasal dari Al-Qur'an yang berhubungan dengan jurusan penulis yaitu Matematika. Hal ini karena penulis sebagai calon guru ingin para siswa tidak hanya mengenal Phytagoras tetapi juga mengenal Al-Khawarizmi, bahkan mereka bangga sebagai muslim

${ }^{6}$ Departemen Agama RI, AlHidayah Al-Qur'an Tafsir Per Kata Tajwid Kode Angka, Op. Cit., hlm. 171.

${ }^{7}$ Mahdi Ghulsyani, Filsafat Sains Menurut Al-Qur'an, diterjemahkan dari "The Holy Quran and the Sciences of Nature" oleh Agus Effendi (Bandung: Mizan, 1998), hlm. 42.

${ }^{8}$ Ariyadi Wijaya, Pendidikan matematika realistik, suatu alternatif pendekatan pembelajaran matematika, (Yogyakarta: Graha Ilmu, 2012), hlm. 20. 
karena semua sumber pengetahuan mereka berasal dari kitab suci AlQur'anul Karim yang telah ditelaah sebelumnya oleh para cendikiawan muslim. Jika sikap bangga para generasi muda terus dipupuk maka keimanan dan nilai-nilai religius mereka dapat terus bertambah.

Dalam penelitian penulis tentang konsep bilangan dalam Al-Qur'an, penulis memberikan batasan masalah hanya pada konsep bilangan rasional saja yaitu himpunan bilangan bulat dan pecahan. Himpunan bilangan bulat yang dikaji penulis yaitu : bilangan cacah, bilangan asli, bilangan prima, bilangan komposit, bilangan ganjil dan bilangan genap. Oleh sebab itu, penulis menggunakan konsep aplikasi bilangan prima seperti konsep pola angka 19 dan konsep bilangan prima kembar yang bertujuan untuk menggambarkan keistimewaan bilangan yang termasuk dalam himpunan bagian bilangan rasional, sehingga tampak bahwa posisi wahyu dan ilmu pengetahuan terintegrasi dengan sempurna.

Karena rasa keingintahuan penulis terhadap konsep bilangan rasional dalam Al-Qur'an, maka penulis termotivasi mengadakan penelitian tentang Konsep Bilangan Rasional dalam Al-Qur'an dan Hubungannya dengan NilaiNilai Religius.

\section{B. Kajian Kepustakaan}

\section{Al-Qur'an dan Ilmu Pengetahuan}

a. Keotentikan Al-Qur'an

Ciri dan sifat dari Al-Qur'an salah satunya adalah Allah menjamin keotentikannya seperti dalam Al-Qur'an Surat Al-Hijr: 9, sebagai berikut:

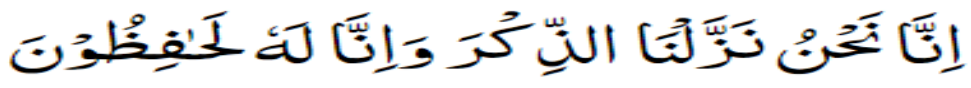

Artinya : Sesungguhnya Kami-lah yang menurunkan AlQur'an, dan pasti kami (pula) yang memeliharanya. (Q.S. al-Hijr:9). ${ }^{9}$

Allah menjamin keotentikan Al-Qur'an atas dasar Kemahakuasaan dan Kemahatahuan-Nya, serta berkat upaya-upaya yang dilakukan oleh Makhluk-Nya, terutama oleh manusia. Dengan jaminan ayat di atas, setiap muslim percaya bahwa apa yang dibacanya dan didengarnya sebagai Al-Qur'an tidak berbeda sedikit pun dengan apa yang dibaca oleh Rasulullah SAW, dan yang didengar serta dibaca oleh para sahabat Nabi SAW. Seperti yang dikemukakan oleh Abdul Halim Mahmud, mantan Syaikh Al-Azhar: "para orientalis yang dari saat ke saat berusaha menunjukkan kelemahan Al-Qur'an, tidak mendapatkan celah untuk meragukan keotentikannya." Hal ini disebabkan oleh bukti-bukti sejarah yang mengantarkan mereka kepada kesimpulan tersebut. ${ }^{10}$

${ }^{9}$ Departemen Agama RI, AlHidayah Al-Qur'an Tafsir Per Kata Tajwid Kode Angka, Op. Cit., hlm. 263.

${ }^{10}$ M. Quraish Shihab, Membumikan Al-Qur'an : Fungsi dan Peran Wahyu dalam Kehidupan Masyarakat Edisi ke-2 (Bandung: Mizan Media Utama (MMU), 2013), hlm. 28. 
Riwayat sejarah menginformasikan bahwa terdapat ratusan sahabat Nabi SAW yang menghafalkan Al-Qur'an. Bahkan dalam peperangan Yamamah, yang terjadi beberapa saat setelah wafatnya Rasul SAW, telah gugur tidak kurang dari tujuh puluh orang penghafal Al-Qur'an.

Walaupun Nabi SAW, dan para sahabat menghafal ayat-ayat Al-Qur'an, guna menjamin terpeliharanya wahyu-wahyu Ilahi, beliau tidak hanya mengandalkan hafalan, tetapi juga tulisan. Sejarah menginformasikan bahwa setiap ada ayat yang turun, Nabi SAW memanggil sahabat-sahabat yang dikenal pandai menulis, untuk menuliskan ayat-ayat yang baru saja diterimanya, sambil menyampaikan tempat dan urutan setiap ayat dalam suratnya. Ayatayat tersebut mereka tulis dalam pelepah kurma, batu, kulit-kulit, atau tulang-tulang binatang. Sebagaian sahabat ada yang menuliskannya secara pribadi, tetapi karena keterbatasan alat tulis dan kemampuan, maka tidak banyak yang melakukannya di samping kemungkinan besar tidak mencakup seluruh ayat Al-Qur'an.

\section{b. Hubungan Al-Qur'an dengan Ilmu Pengetahuan}

Pandangan Al-Qur'an tentang ilmu dan tekhnologi dapat dilihat dari analisis wahyu pertama yang diterima oleh Nabi SAW yaitu dalam Al-Qur'an Surat Al-'Alaq ayat 1-5.

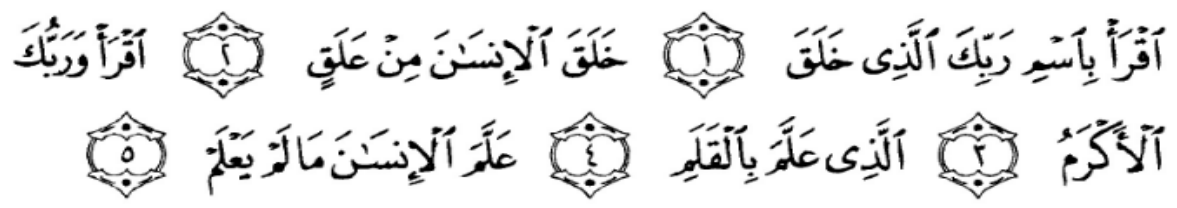

Artinya : Bacalah dengan (menyebut) nama Tuhanmu yang menciptakan. Dia telah menciptakan manusia dari segumpal darah. Bacalah, dan Tuhanmulah Yang Maha Mulia. Yang mengajar (manusia) dengan pena. Dia yang mengajarkan manusia apa yang tidak diketahuinya. (Q.S. al-'Alaq:1-5) ${ }^{11}$

Iqra' terambil dari akar kata menghimpun. Dari menghimpun lahir aneka makna seperti meyampaikan, menelaah, mendalami, meneliti, mengetahui ciri sesuatu,, dan membaca baik teks tertulis maupun tidak. Wahyu pertama itu tidak menjelaskan apa yang harus dibaca, karena Al-Qur'an menghendaki umatnya membaca apa saja selama bacaan tersebut bismi Rabbik, dalam arti manfaat untuk kemanusiaan. Iqra' berarti bacalah, telitilah, dalamilah, ketahuilah, ciri-ciri sesuatu; bacalah alam, tanda-tanda zaman, sejarah, maupun diri sendiri, yang tertulis maupun yang tidak. Alhasil, objek perintah iqra' mencakup segala sesuatu yang dapat menjangkaunya. ${ }^{12}$

${ }^{11}$ Departemen Agama RI, AlHidayah Al-Qur'an Tafsir Per Kata Tajwid Kode Angka, Op. Cit., hlm. 598.

425 .

${ }^{12}$ M. Quraish Shihab, Wawasan Al-Qur'an (Bandung: Mizan, 1996), hlm. 
Kata ilmu dengan berbagai bentuknya terulang 854 kali dalam Al-Qur'an. Kata ini digunakan dalam arti proses pengetahuan dan objek pengetahuan. 'Ilm dari segi bahasa berarti kejelasan, karena itu segala yang terbentuk dari akar katanya mempunyai ciri kejelasan. Contohnya kata 'alam (bendera), 'ulmat (bibir sumbing), a'lam (gunung-gunung), dan sebagainya. Ilmu adalah pengetahuan yang jelas tentang sesuatu, sekalipun demikian, kata ini berbeda dengan kata 'arafa (mengetahui) a'rif (yang mengetahui) dan ma'rifah (pengetahuan).

Dalam pandangan Al-Qur'an, ilmu adalah keistimewaan yang menjadikan manusia unggul dari makhluk-makhluk lain yang telah Allah ciptakan di muka bumi ini, sehingga manusia dapat menjalankan fungsinya sebagai kekhalifahannya. Hal ini tampak dari firman Allah SWT dalam Al-Qur'an surat al-Baqarah ayat : 31-32, yaitu :

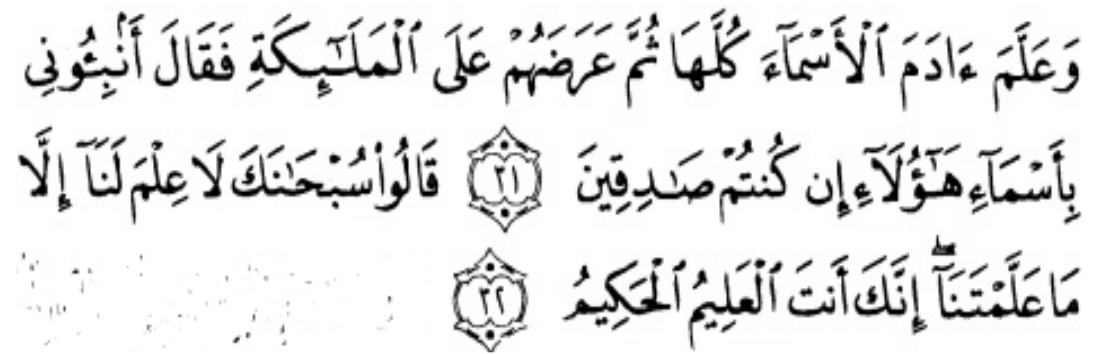

Artinya : Dan Dia ajarkan kepada Adam nama-nama (benda) semuanya, kemudian Dia perlihatkan kepada para malaikat, seraya berfirman, "Sebutkan kepada-Ku nama semua (benda) ini, jika kamu yang benar!" Mereka menjawab, "Mahasuci Engkau, tidak ada yang kami ketahui Selain apa yang telah Engkau ajarkan kepada kami. Sungguh, Engkaulah Yang Maha Mengetahui, Mahabijaksana. (Q.S. al-Baqarah:31-32). ${ }^{13}$

Dari penjelasan ayat dapat dipahami bahwa Allah memberikan manusia potensi dalam mencari, memahami dan mengamalkan ilmu. Bahkan Allah sendiri menyatakan bahwa kedudukan yang tertinggi di mata Allah adalah orang-orang bertaqwa yang berpengetahuan.

\section{c. Keterkaitan Matematika dengan Agama}

Sebelumnya penulis telah memaparkan pada bab kajian teori tentang hubungan antara Al-Qur'an dengan ilmu pengetahuan bahwa Al-Qur'an dan ilmu pengetahuan terintegrasi sesuai dengan kajian teori tentang hubungan antara Al-Qur'an dan ilmu pengetahuan, sedangkan kaitan antara matematika khususnya pada pembahasan konsep bilangan atau angka dengan agama sebagai ilmu yang mengajarkan norma-norma berdasarkan Al-Qur'an dan Hadist, yaitu :

${ }^{13}$ Departemen Agama RI, AlHidayah Al-Qur'an Tafsir Per Kata Tajwid Kode Angka, Op. Cit., hlm. 7. 
a. Angka atau bilangan merupakan dasar atau pokok dalam melakukan operasi perhitungan. Dengan bilangan maka kita dapat melakukan perhitungan perjalanan waktu sehingga manusia melakukan perhitungan yang akurat bahwa manusia harus mengisi waktu tersebut dengan penuh manfaat sehingga seperti yang dipaparkan dalam Al-Qur'an Surat Al-'Asr: 1-3, yang artinya : Demi masa. Sungguh, manusia berada dalam kerugian. Kecuali orang-orang yang beriman dan mengerjakan kebajikan serta saling menasihati untuk kebenaran dan saling menasihati untuk kesabaran. (Q.S. Al-'Asr:1-3). ${ }^{14}$

b. Angka atau bilangan ini juga berkaitan dengan perhitungan dosa dan pahala sehingga manusia dapat memperhitungkan dengan seksama tentang persiapan manusia untuk menghadapi negeri baru nantinya yang kekal dan abadi yaitu akhirat. Maka dengan adanya bilangan atau angka ini dapat dijadikan sebagai wadah untuk evaluasi diri untuk menjauhi dosa dan selalu mengerjakan kebajikan yang telah diatur oleh Allah SWT di dalam Al-Qur'an dan Hadist.

c. Angka atau bilangan ini juga menunjukkan keajaiban dan Mukjizat Al-Qur'an yang telah kita bahas sebelumnya pada konsep-konsep bilangan tersebut, ini diharapkan dapat mempertebal keimanan umat muslim dan mungkin saja dapat menjadi hidayah bagi orangorang kafir.

\section{d. Konsep Bilangan dalam Al-Qur'an}

Ada beberapa konsep bilangan dalam Al-Qur'an yang juga merupakan konsep bilangan dalam bahasa Arab yang disebut juga konsep Al-A'dad wal Ma'dud, yaitu: 1) Adad Mufrad, 2) 'Adad Murakkab, 3) 'Adad 'Aqd, 4) 'Adad Ma'thuf.

\section{e. Penyebutan Bilangan dalam Al-Qur'an}

Dalam Al-Qur'an telah disebutkan 38 bilangan yaitu 8 bilangan pecahan dan 30 bilangan bulat. Karena pendekatan yang digunakan penulis adalah berpikir induktif sebagai acuan dalam mengamati himpunan bilangan yang disebutkan dalam Al-Qur'an berupa teks, sehingga penulis memulai kajian dari bilangan genap dan ganjil, kemudian bilangan bulat dan diakhiri dengan bilangan pecahan sebagai ciri khas dari himpunan bilangan rasional dan irrasional.

\section{f. Nilai-nilai Religius}

Nilai-nilai religius berasal dari kata Nilai dan Religius. Nilai menurut Lorens Bagus dalam bukunya yang berjudul Kamus Filsafat yaitu : nilai berasal dari bahasa Inggris yaitu kata value, dan dari bahasa Latin yaitu kata valere yang berarti berguna, mampu akan,

${ }^{14}$ Departemen Agama RI, AlHidayah Al-Qur'an Tafsir Per Kata Tajwid Kode Angka, Op. Cit., hlm. 602. 
berdaya, berlaku, kuat. Dan dari beberapa pengertian bahwa nilai adalah :

a. Harkat. Kualitas suatu hal yang menjadikan hal itu dapat disukai, diinginkan, berguna, atau dapat menjadi objek kepentingan.

b. Keistimewaan: Apa yang dihargai, dinilai tinggi, atau dihargai sebagai suatu kebaikan. Lawan dari suatu nilai positif adalah "tidak bernilai" atau "bernilai negatif". Baik akan menjadi suatu nilai dari lawannya (jelek, buruk) akan menjadi suatu "nilai negatif" atau "tidak bernilai".

c. Ilmu Ekonomi, yang bergelut dengan kegunaan dan nilai tukar benda-benda material, pertama kali menggunakan secara umum kata "nilai". 15

Nilai adalah suatu penetapan atau kualitas objek yang menyangkut suatu apresiasi atau minat. Dalam Islam yang menentukan asas-asas penilaian adalah $R a b b$, dan yang merumuskan serta melaksanakan nilai-nilai tersebut adalah manusia sebagai khalifah di bumi. ${ }^{16}$ Jadi nilai adalah sesuatu yang berharga, bermutu, menunjukkan kualitas, dan berguna bagi manusia. Sesuatu itu bernilai jika sesuatu itu berharga atau berguna bagi kehidupan manusia. Nilai sebagai kualitas yang independen akan memiliki ketetapan yaitu tidak berubah yang terjadi pada objek yang dikenai nilai. Menilai juga dapat dikatakan sebagai kegiatan menghubungkan sesuatu dengan sesuatu yang lain sehingga diperoleh menjadi suatu keputusan yang menyatakan sesuatu itu berguna atau tidak berguna, benar atau tidak benar, baik, atau buruk, manusiawi atau tidak manusiawi, religius atau tidak religius, berdasarkan jenis tersebutlah nilai ada.

Sedangkan religius adalah menurut kamus besar bahasa Indonesia bahwa religius adalah bersifat religi atau keagamaan yang maksudnya adalah yang bersangkut paut dengan religi atau keagamaan. ${ }^{17}$ Religius atau keagamaan yang dimaksud penulis adalah religi Islam. Maka dapat dengan kata lain bahwa Religi merupakan suatu kesadaran yang menggejala secara mendalam dalam lubuk hati manusia sebagai human nature, bukan hanya menyangkut segi kehidupan secara lahiriah melainkan juga menyangkut keseluruhan diri pribadi manusia secara total dalam integrasinya hubungan ke dalam keesaan Allah.

Sehingga dapat disimpulkan bahwa nilai-nilai religius adalah sesuatu yang berharga, bermutu, menunjukkan kualitas, dan berguna bagi manusia dalam bentuk suatu kesadaran yang menggejala secara mendalam dalam lubuk hati manusia sebagai human nature,

${ }^{15}$ Lorens Bagus, Op. Cit., hlm. 713-714.

${ }^{16}$ Fakhrurrazy Dalimunthe dkk, Op. Cit., hlm. 84.

${ }^{17}$ Departemen Pendidikan dan Kebudayaan, Op. Cit., hlm. 944. 
bukan hanya menyangkut segi kehidupan secara lahiriah melainkan juga menyangkut keseluruhan diri pribadi manusia secara total dalam integrasinya hubungan ke dalam keesaan Allah. Nilai-nilai religius menurut Adisusilo dalam bukunya yang berjudul pembelajaran nilai-nilai karakter yang diungkapkan oleh Edi Mustaqim memiliki sejumlah indikator yaitu :

1) Nilai memberi tujuan atau arah (goal or purpose).

Nilai memberi tujuan atau arah maksudnya adalah adanya rasa untuk meningkatkan kualitas secara lahiriah yang berhubungan dengan Allah manusia memiliki tujuan dan arah hidup. Cahaya Ilahi menuntun mereka bertujuan menjadi pribadi yang memiliki iman yang kuat, jiwa yang taqwa yang tempat kembali mereka nantinya hanya kepada Allah setelah kematian mereka. Jika mereka sudah dikumpulkan di yaumul mahsyar maka mereka telah setiap untuk menerima ganjaran dari hasil perhitungan amal mereka selama hidup di dunia berupa pahala dan dosa, apakah nantinya mereka ditempatkan di surga atau di neraka karena inilah yang menjadi tujuan akhir dalam kehidupan manusia.

2) Nilai memberi aspirasi (aspiration).

Nilai memberi aspirasi maksudnya dalam peningkatan kualitas kerohanian seseorang, ada hal yang menjadi pemacu meningkatnya kualitas keimanan dan ketakwaan seseorang, misalnya saja cerita-cerita kenabian yang memiliki kepribadian luar biasa yang menjadi contoh dalam peningkatan kualitas hidup manusia atau peristiwa yang lampau yang telah disampaikan Allah di dalam Al-Qur'an sehingga menjadi pelajaran yang berharga bagi manusia dalam bertindak.

3) Nilai mengarahkan seseorang untuk bertingkah laku (attitude).

Nilai mengarahkan seseorang untuk bertingkah laku maksudnya adalah jika di dalam Al-Qur'an Allah telah menjelaskan hal-hal yang berupa baik atau benar, larangan atau perintah, ganjaran berupa pahala dan dosa baik dari segi history maka manusia memiliki pilihan dalam perkataan, sikap maupun perbuat sehingga dapat mengarahkan manusia dalam bertindak dan bertingkah laku.

4) Nilai itu menarik (interest).

Nilai itu menarik maksudnya adalah ada sesuatu nilai lebih yang didapatkan seseorang sehingga menjadi daya tarik bagi manusia dalam meningkatkan kerohanian mereka dan berusaha memperbaiki kualitas keimanan dan ketakwaan mereka.

5) Nilai mengusik perasaan (feelings).

Nilai mengusik perasaan maksudnya adalah di dalam AlQur'an Allah menjelaskan berbagai hal baik berupa pernyataan bahwa Allah senang akan orang-orang yang sabar atau pernyataan bahwa betapa murkanya Allah dengan orang-orang dzalim yang selalu berbuat kerusakan di bumi, hal inilah yang mengundang perasaan manusia untuk takut kepada kemurkaan Allah dan 
bertambah kecintaannya kepada Allah jika mereka evaluasi diri betapa banyaknya nikmat yang telah diberikan Allah.

6) Nilai terkait dengan keyakinan atau kepercayaan (beliefs and convictions). ${ }^{18}$

Nilai terkait dengan keyakinan atau kepercayaan maksudnya adalah di dalam Al-Qur'an ada sesuatu hal yang membuat manusia semakin yakin dan percaya bahwa Allah itu ada sebagai Tuhan mereka dan mereka juga yakin dan percaya bahwa setiap pernyataan yang diberikan Allah, atau sebuah kisah yang disampaikan Allah di dalam Al-Qur'an benar-benar ada dan terjadi baik jika diamati dari pengalaman berupa sejarah yang mengisahkannya, atau sesuatu yang belum terjadi, atau sesuatu yang belum tampak tetapi telah dijanjikan Allah bahwa semua itu ada dan benar-benar akan terjadi. Semua hal ini menyangkut keimanan dan kepercayaan seseorang bahwa semua ini benar dan mutlak benar.

\section{Hasil dan Pembahasan}

\section{Konsep Himpunan}

Teori himpunan merupakan bidang matematika yang mengkaji himpunan (set), yakni kumpulan (koleksi) dari objek-objek yang terdefinisi dengan jelas (well defined). Makna "objek" dalam definisi tersebut dapat berupa obyek nyata dan abstrak. Adapun makna "terdefinisi dengan jelas" adalah ciri, sifat, atau syarat objek yang dimaksud harus jelas dan dapat ditentukan. Ciri, sifat, atau syarat objek tersebut merupakan prinsip keanggotaan dalam suatu himpunan. Misalnya saja, kumpulan hewan berkaki empat. Obyek-obyek yang dimaksud dalam contoh tersebut sudah jelas, yakni hewan yang memiliki jumlah kaki sebanyak empat, seperti kuda, domba, kerbau, sapi, dan lain sebagainya. Pada dasarnya secara rasional Al-Qur'an telah menyiratkan ide mengenai prinsip himpunan tersebut. Misalnya dalam Al-Quran surat Al-Fathir ayat 1, yaitu:

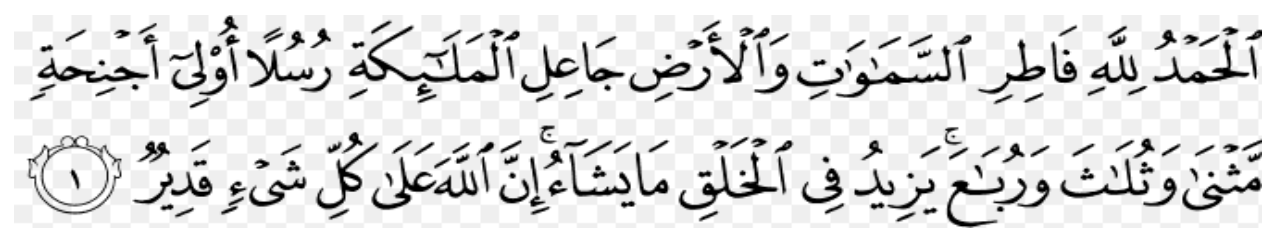

18

Edi Mustaqim,

"Nilai

Religius"

(https://www.academia.edu/4731434/integrasi

nilai_religius

melalui_ pendekatan_SETS_pada_pembelajaran_biologi, diakses 09 Maret 2014 pukul 21.00 WIB). 
Artinya : Segala puji bagi Allah Pencipta langit dan bumi, yang menjadikan malaikat sebagai utusan-utusan (untuk mengurus berbagai macam urusan) yang mempunyai sayap, masing-masing (ada yang) dua, tiga, dan empat. Allah menambahkan pada ciptaan-Nya apa yang Dia kehendaki. Sungguh, Allah Maha Kuasa atas segala sesuatu. (Q.S. Al-Fathir:1). ${ }^{19}$

Dalam ayat di atas, dijelaskan sekelompok makhluk yang disebut malaikat. Dalam kelompok malaikat tesebut memiliki dua sayap, tiga sayap, atau empat sayap. Ketiga kelompok malaikat tersebut syaratnya sudah sangat jelas meskipun malaikat merupakan makhluk yang abstrak, ini sama seperti karakteristik matematika yang objek kajiannya juga abstrak. Lalu, dijelaskan juga pada ayat tersebut pada kata "utusan-utusan" ini merupakan perwakilan dari kata yang menjelaskan tentang keanggotaan himpunan. Kemudian dijelaskan bahwa malaikat tersebut yakni malaikat dengan jumlah sayap yang sama.

\section{Konsep Bilangan Rasional}

"Bilangan rasional adalah : sebarang bilangan yang dapat dinyatakan sebagai pecahan. Secara ekuivalen, sebuah bilangan rasional adalah sebarang bilangan yang dapat ditulis sebagai bilangan desimal yang dapat ditulis sebagai bilangan desimal yang berakhir atau berulang." 20 Dapat dikatakan bilangan rasional adalah himpunan bilangan bulat dan pecahan serta bilangan desimal.

Bilangan rasional adalah hasil bagi antara dua bilangan, yang berupa bilangan bulat, atau berupa pecahan dengan desimal terbatas, atau desimal berulang. Sedangkan bilangan irrasional adalah hasil bagi antara dua bilangan, berupa pecahan dengan desimal tak terbatas dan berulang, termasuk bilangan $\pi$ dan bilangan $e$. Bilangan bulat adalah hasil bagi antara dua bilangan yang hasilnya bulat, termasuk 0 (nol). Bilangan pecahan adalah hasil bagi antara dua bilangan yang hasilnya pecahan dengan desimal terbatas atau desimal berulang. ${ }^{21}$

Dengan menggunakan pendekatan teori himpunan maka, terdapat beberapa karakteristik bilangan yaitu :

a) Semua bilangan bulat adalah bilangan rasional, tetapi tidak semua bilangan rasional merupakan bilangan bulat.

b) Semua bilangan pecahan adalah bilangan rasional, tetapi tidak semua bilangan rasional berupa bilangan pecahan.

${ }^{19}$ Departemen Agama RI, AlHidayah Al-Qur'an Tafsir Per Kata Tajwid Kode Angka, Op. Cit., hlm. 435 .

20 Suyono, Matematika Sekolah Dasar dan Menengah Jilid, Diterjemahkan dari "Elementary and Middle School Mathematics"oleh John A. Van de Walle (Jakarta: Erlangga, 2006), hlm. 247.

${ }^{21}$ Dumairy, Op. Cit., hlm. 14. 
Semua bilangan irrasional adalah bilangan berdesimal, tetapi tidak semua bilangan berdesimal adalah bilangan irrasional.

\section{Konsep Bilangan Cacah}

Bilangan cacah merupakan himpunan bilangan Bulat positif yang dimulai dari bilangan 0 sampai tak terhingga. Himpunan bilangan cacah disimbolkan dengan huruf $W$ (whole numbers). ${ }^{22}$ Secara matematis dapat ditulis dengan simbol sebagai berikut: $W=\{0$, $1,2,3, \ldots\}$.

Yang menjadi angka atau bilangan pembeda pada himpunan bilangan cacah adalah anggota himpunan bagiannya yaitu angka atau bilangan 0 . Konsep bilangan 0 dalam Al-Qur'an dapat diinterpretasikan dari kata-kata yang sangat sering diucapkan oleh kaum muslim yaitu Kalimat Syahadat. Makna La Ilaha Illallah berkaitan dengan angka 1 dan 0 , yaitu :

La Ilaha $=$ tidak ada Tuhan (tidak ada $=$ berarti konsep bilangan atau angka 0 , sedangkan kata Tuhan = konsep bilangan atau angka 1 yang berarti Esa).

Illallah $=$ selain Allah ( kata selain Allah merupakan konsep Keesaan Allah yang menegaskan bahwa Tuhan hanyalah Allah, sehingga penegasan ini menggambarkan tentang angka $=1)$.

\section{Konsep Bilangan Prima dan Komposit}

Bilangan prima adalah himpunan bilangan yang terdiri dari angka atau bilangan yang anggotanya hanya bisa dibagi oleh angka 1 atau bilangan itu sendiri. Himpunannya yaitu : $P=\{2,3,5,7,11,13$, $17,19, \ldots\}$.

Dalam Al-Qur'an bilangan atau angka 2, 3, 5, 7 dan 11 sudah dijelaskan sebelumnya pada konsep bilangan bulat. Sedangkan angka atau bilangan 13 adalah banyaknya penyebutan pada kata faqir yang berarti membutuhkan. ${ }^{23}$ Sedangkan angka atau bilangan 5 juga dapat ditinjau dari perintah shalat 5 waktu yang juga disebutkan 5 kali dalam Al-Qur'an dan jumlah rakaat pada shlat 5 waktu tersebut juga menunjukkan bilangan prima yaitu $: \underline{\text { Shubuh }=2 \text {, Dzhuhur }=4 \text {, Ashar }}$ $=4$, Maghrib $=3$, dan Isya $=4$.

Maka total jumlah rakaatnya yaitu $2+4+4+3+4=17$ rakaat.

Sedangkan pada rahasia angka 19 merupakan angka istimewa dalam numerik Al-Qur'an. Pada keistimewaan angka 19 ini akan penulis paparkan pada bab pembahasan. Banyak metode yang dapat mengungkapkan keistimewaan angka 19, tetapi penulis akan memaparkan hadirnya angka 19 ini dari susunan Juz Al-Qur'an. Al2014 pukul 09.28 WIB).

${ }^{23}$ Caner Taslaman, Op. Cit., hlm. 350. 
Qur'an terdiri dari 30 juz dan angka 30 merupakan bilangan komposit atau pelengkap sehingga ketika digabungkan dengan bilangan prima akan membentuk bilangan asli. Jika disusun pada banyaknya Juz AlQur'an, maka akan terbentuk susunan bilangan prima dan komposit.

\section{Konsep Bilangan Genap dan Ganjil}

Bilangan Genap adalah bilangan yang habis dibagi dua (maksudnya adalah bilangan yang terbagi dua tanpa sisa), sedangkan bilangan ganjil adalah bilangan yang tidak dapat dibagi oleh dua. Bilangan genap dapat juga dinyatakan sebagai bilangan bulat yang kongruen 0 modulo 2, dan bilangan ganjil adalah bilangan bulat yang kongruen dengan 1 modulo 2.

Selain itu juga terdapat lubang hitam dalam bilangan (black hole) yaitu bilangan $(1,2,3)$, dengan peraturan bahwa urutan pertama menunjukkan bilangan genap, urutan kedua menunjukkan bilangan ganjil, kemudian di urutan terakhir akan menunjukkan jumlah seluruh bilangan yang sedang kita olah untuk masuk ke dalam lubang hitam bilangan yaitu $(1,2,3)$. Peraturan yang lainnya yaitu bahwa bilangan 0 merupakan bilangan genap. ${ }^{24}$

Dari penjelasan di atas sangat jelas terlihat bahwa konsep bilangan rasional dalam Al-Qur'an berhubungan dengan nilai religius. Sehingga terbukti benar dengan pendekatan filsafat yang penulis gunakan karena dari hasil pemikiran yang radikal dan secara universal tampak bahwa secara empiris dan logika matematis bahwa konsep bilangan rasional terintegrasi dengan konsep bilangan rasional yang ada dalam AlQur'an dan menunjukkan nilai-nilai religius yang berdasarkan tinjauan indikator nilai yang telah diungkapkan oleh Adisusilo.

\section{Penutup}

\section{KESIMPULAN}

Dari hasil pembahasan tersebut penulis dapat menyimpulkan bahwa:

a. konsep bilangan dalam Al-Qur'an juga merupakan konsep bilangan dalam bahasa Arab. Bilangan-bilangan rasional dalam Al-Qur'an ada sebagian yang langsung disebutkan atau dengan kata lain dikaji secara teks, tetapi tidak secara keseluruhan dalam himpunan bilangan rasional. Maka dari itu digunakan pemahaman secara konteks misalnya saja dengan penginterpretasian bilangan nol (0) dan konkordansi leksikal matematis yaitu berupa hubungan kata per kata yang ada dalam Al-Qur'an dengan menggunakan kitab Al-Mu'jam Al-Mufarash untuk mendapatkan data yang otentik pada sistem bilangan pada matematika kontemporer yang khusus membahas tentang bilangan rasional, sehingga dalam mengintegrasikan bilangan rasional dalam 
Al-Qur'an dengan konsep bilangan rasional dalam matematika kontemporer menjadi lebih terarah dan mudah dipahami.

b. Semua ini untuk menggambarkan kekuasaan Allah SWT dari penjabaran teori-teori yang berkaitan. Hasil pembahasan berupa hubungan bilangan dalam Al-Qur'an dengan nilai-nilai religius yang tampak dari penafsiran kata-kata dari kata "bilangan" hingga penyebutan secara teks bilangan dari bilangan pecahan rasional hingga bilangan yang terbesar yaitu bilangan "100.000" yang diinterpretasikan dalam bentuk indikator nilai religius yaitu : nilai memberi tujuan atau arah (goal or porpuse), nilai memberi aspirasi (aspiration), nilai mengarahkan seseorang untuk bertingkah laku (attitude), nilai itu menarik (Intertesti), nilai mengusik perasaan (feelings), dan nilai terkait dengan keyakinan dan kepercayaan (beliefs and convictions). Karena semua kata yang ditafsirkan tersebut dari terjemahan Al-Qur'an semuanya memiliki indikator nilai religius minimal satu indikator maka dapat disimpulkan bahwa konsep bilangan rasional dalam Al-Qur'an memiliki hubungan dengan nilainilai religius.

\section{Saran}

Beberapa saran berikut dapat menjadi bahan masukan yang bermanfaat bagi pihak-pihak terkait antara lain.

1. Penulis berharap agar siswa dalam belajar khususnya matematika tidak hanya memahami rumus-rumus yang ada tetapi dapat mengaitkan antara ilmu pengetahuan seperti matematika dengan ilmu agama sehingga dapat memperkuat nilai-nilai religius yang mulai memudar. Penulis juga berharap para siswa memiliki rasa bangga yang besar karena puncak ilmu pengetahuan adalah wahyu dari Allah berupa AlQur'an dan hadist yang merupakan kitab yang diimani oleh orang muslim.

2. Penulis berharap Lembaga Pendidikan Islam memberikan beberapa kebijakan dan fasilitas agar di dalam buku pegangan siswa selalu terdapat nilai-nilai religius yang dapat dipetik oleh para siswa dan kalau bisa guru dan Lembaga Pendidikan Islam agar menganalkan ilmu pengetahuan yang bersesuaian dengan materi ajar tetapi terkait dengan Al-Qur'an.

3. Tenaga pendidik hendaknya tidak terlalu membuat batasan berpikir anak pada domain matematika saja atau agama saja. Penulis berharap para guru memasukkan beberapa konsep ilmu pengetahuan yang juga didapatkan dari konsep pengetahuan yang ada di dalam Al-Qur'an, sehingga para peserta didik tidak merasa asing dengan Al-Qur'an. Penulis juga berharap agar guru bersedia untuk mengenalkan para ilmuwan muslim yang berjasa dengan ilmu pengetahuan jadi tidak hanya mengenal para penemu dari Barat. 


\section{DAFTAR PUSTAKA}

Achmad Baiquni, Al-Qur'an dan Ilmu Pengetahuan Kealaman, Yogyakarta: PT Dana Bhakti Prima Yasa, 1996.

Adisusilo Sutarjo, Pembelajaran Nilai-nilai Karakter, Jakarta: Rajawali Press, 2012.

Andi Rosadisastra, Metode Tafsir Ayat-ayat Sains dan Sosial, Jakarta: Amzah, 2007.

Archemadfaroeqs, Bilangan dalam Al-Qur'an (http://achemadfaroeqs. wordpress.com/2012/11/08/bilangan-dalam-al-quran/, diakses 21 Januari 2014 pukul 09.28 WIB).

Ariyadi Wijaya, Pendidikan matematika realistik, suatu alternatif pendekatan pembelajaran matematika, Yogyakarta: Graha Ilmu, 2012.

A. Rifqi Amin, Penelitian Kepustakaan, (http://banjirembun. blogspot.com/2012/04/penelitian-kepustakaan.html, diakses 25 Maret 2014 pukul 09.30 WIB).

Dalimunthe Fakhrurrazy, dkk, Filsafat Pendidikan Islam, Medan: IAIN SU Press, 1996.

Djati Kerami Cormentyna Sitanggang, Kamus Matematika, Jakarta: Balai Pustaka, 2003.

Departemen Agama RI, AlHIdayah Al-Qur'an Tafsir Per Kata Tajwid Kode Angka, Banten: PT Kalim, 2010.

..Metodologi pendidikan Agama Islam, Jakarta: Direktorat Jenderal Pembinaan Kelembagaan agama Islam, 2001.

Departemen Pendidikan dan Kebudayaan, Kamus Besar Bahasa Indonesia Edisi Ketiga, Jakarta: Balai Pustaka, 2001.

Dumairy, Matematika Terapan Untuk Bisnis dan Ekonomi Edisi Kedua, Yogyakarta: BPFE-Yogyakarta, 2012.

Edi Mustaqim, Nilai Religius (http://www.academia.edu/4731434/ntegrasi nilai religius melalui pendekatan SETS pada pembelajaran biologi, diakses 09 Maret 2014 pukul 21.00 WIB).

H.M. Arifin, Al-Qur'an Sumber Ilmu Pengetahuan, Jakarta: PT Rineka Cipta, 1992.

Hollads Roy, Kamus Matematika, Jakarta: Erlangga, 1999.

Jalaluddin, Psikologi Agama Memahami Perilaku dengan Mengaplikasikan Prinsip-prinsip Psikologi Edisi Revisi 2012, Jakarta: PT Raja Grafindo Persada, 2012.

Juliansyah Noor, Metodologi Penelitian Skripsi, Tesis, Disertasi, \& Karya Ilmiah, Jakarta: Kencana Prenada Media Group, 2013.

Jonathan Lyons, The Great Bait Al-Hikmah Kontribusi Islam dalam Peradaban Barat, Bandung: PT Mizan Publika, 2013.

Komaruddin Hidayat, Memahami Bahasa Agama Sebuah Kajian Hermeneutika Bandung : PT Mizan Pustaka, 2011.

Khoirunnas Anfa'ahum Linnas, Matematika, Bilangan Prima dan Bilangan Penciptaan (http://www.angelfire.com/on2/daviddarling/AreciboM.htm, diakses 21 januari 2014 pukul 11.00 WIB).

Lexy J. Moleong, Metodologi Penelitian Kualitatif, Bandung: Rosdakarya, 2000. 
Liza Septa Sari, Bilangan Ganjil dan Keistimewaannya di dalam Al-Quur'an (http://lizaseptasarie.wordpress.com/pelajaran/bil-ganjil-dan-

keistimewaannya-di-dalam-al-quran/, diakses tanggal 21 Januari 2014 pukul 09. 40 WIB).

Lorens Bagus, Kamus Filsafat, Jakarta: PT Gramedia Pustaka Utama, 2000.

Mahdi Ghulsyani, Filsafat Sains Menurut Al-Qur'an, Bandung: Mizan, 1998.

Mardalis, Metode Penelitian Suatu Pendekatan Proposal, Jakarta: Bumi Aksara, 2003.

M. Nababan, Pengantar Matematika Untuk Ilmu Ekonomi dan Bisnis, Jakarta: Erlangga, 2007.

M. Quraish Shihab, Wawasan Al-Qur'an, Bandung: Mizan, 1996. .. Membumikan Al-Qur'an : Fungsi dan Peran Wahyu dalam Kehidupan Masyarakat Edisi ke-2, Bandung: Mizan Media Utama (MMU), 2013.

Muhammad Abdul Halim, Memahami Al-Qur'an, Bandung: Marja, 2002.

Murtadha Muthahhari, "Manusia dan Alam Semesta, Jakarta: PT Lentera Basritama, 2002.

Nana Sudjana, Tuntunan Penyusunan Karya Ilmiah Makalah-Skripsi-TesisDisertasi, Bandung: Sinar baru Alegensindo, 2001.

Nanang Gozali, Manusia, Pendidikan, dan Sains dalam Perspektif Tafsir Hermeneutik, Jakarta: Rineka Cipta, 2004.

Noeng Muhadjir, Ilmu Pendidikan Sosial Suatu Teori Pendidikan Edisi V, Yogyakarta: Ravie Sarasin, 1993.

............, Metodologi Penelitian Kualitatif, Yogyakarta: Rake Sarasin, 1990.

Ritonga Asnil Aidah, Diktat Ulumul Qur'an, Medan: Fakultas Tarbiyah IAIN-SU Press, 2008.

Sayid Muhammad Husaini Behesti, Metafisika Al-Qur'an: Menangkap Intisari Tauhid, Bandung: Mizan, 2003.

Siregar Parluhutan, Penelitian Al-Qur'an Paradigma, Metode, Teknik, Medan: IAIN Press, 2011.

Sitompul Darwini, Kebenaran Wujud Diri, Medan: Madju, 2009.

Sugiyono, Metode Penelitian Pendidikan Pendekatan Kuntitatif, Kualitatif, dan $R \& D$, Bandung: Alfabeta, 2013.

Suharsimi Arikunto, Manajemen Penelitian, Jakarta: Bina Aksara, 1989.

Sutrisno Hadi, Metodologi Research, Yogyakarta: Andi, 2001.

Syarbini, Buku Pintar Pendidikan Karakter, Jakarta: Asa Prima, 2012

Taslaman Caner, Miracle Of The Quran Mengungkap Penemuan-penemuan Ilmiah Modern, Bandung: Mizan, 2011.

Wisnu Arya Wardhana, Al-Qur'an dan Energi Nuklir, Yogyakarta: Pustaka pelajar, 2009.

Yusuf Yahya, dkk., Matematika Dasar Perguruan Tinggi, Bandung: Ghalia Indonesia, 2013.

Zainal dan Fedy, Himpunan Rumus-Rumus Matematika Lengkap, Surabaya: Indah, 2006. 